\title{
Hyoid bone release and end-to-end anastomosis on stenosis of the trachea
}

Hartono Abdoerrachman, Bambang Hermani

\begin{abstract}
Abstrak
Di bidang THT, stenosis trakea masih merupakan keadaan patologi yang sulit diatasi. Dari waktu ke waktu, berbagai usaha telah dilakukan untuk mendapatkan cara yang tepat dan terbaik guna mengatasi stenosis trakea. Kelihatannya cara yang terbaik sangat tergantung pada berat-ringannya penyakit dengan melihat situasi dan kondisi kasus per kasus. Kadang-kadang diperlukan tindakan berulang, dan kombinasi dari beberapa cara harus dipertimbangkan. Beberapa cara yang dianjurkan oleh para ahli akan dibahas dalam makalah ini. Juga dilaporkan sebuah kasus stenosis trakea yang disebabkan intubasi lama, dengan kombinasi tindakan untuk mengatasinya. Penglepasan os hyoid akan memperpanjang trakea yang direseksi dan kombinasi end-to-end dan pemasangan T-tube mencegah timbulnya kembali stenosis di daerah trakea yang dijahit.
\end{abstract}

\begin{abstract}
In the field of Otorhinolaryngology, the treatment of tracheal stenosis is still subject to great problems. Attempts to treat the tracheal stenosis had been done from time to time in order to establish the proper and the best method. It seems that the proper method of treatment depends on the severity of the disease as well as the situation and condition of each case. Sometimes repititive treatment is necessary and moreover, combination of the procedures should be considered. Several methods advocated by the experts were discussed in this paper. A case of stenosis of the trachea due to prolonged intubation is reported, and the combined treatment is discussed. Hyoid bone release enables longer resection and approximation of trachea and combination of end-to-end anastomosis and insertion of T-tube prevents the reoccurance of stenosis on stitched area.
\end{abstract}

Keywords: tracheal stenosis, end to end anastomosis, $T$-tube instalation

Tracheal stenosis is a rarely found case and still a problem and difficult to be solved, which sometimes need a continues handling or repeated interventions, even combination of the procedures. There have been several procedures advocated by the experts, as listed below.

End-to-end anastomosis is one of the attempt to overcome the stenosis, and in this case the anastomosis was combined with insertion of a T-tube as a stent for a certain period of time.

Stenosis of the trachea is a narrowing of tracheal lumen up to or more than $70 \%^{1}$ or reduction of the diameter of the lumen up to $3 \mathrm{~mm}$. Hence, a tube with outer diameter of $4.5 \mathrm{~mm}$ could not pass the stenotic area. ${ }^{2}$ Andrew and Pearson found $17.5 \%$ out of 103 tracheostomized cases, suffered from different degree of stenosis. $^{3}$

Department of Otorhinolaryngology, Faculty of Medicine, University of Indonesia, Jakarta, Indonesia
Soejak in Surabaya found 5 stenosis cases within 5 years. ${ }^{4}$ Our case collection in ENT Dept. RSCM reveals 24 tracheal stenosis within 15 years of accumulated data. ${ }^{5}$

As the etiology of tracheal stenosis, several factors could be listed: ${ }^{6}$

- high volume of the cuff : this causes ischaemia on tracheal wall, leading to necrosis and finally stenosis during healing process.

- impaired vascularisation on tracheal mucosa : this condition leads to ischaemia, necrosis and finally stenosis.

- infection around the cuff will also cause necrosis and leads to stenosis.

- piston action will cause laceration, and leads to stenosis on healing process.

- tracheal movements on coughing will cause laceration, and leads to stenosis on healing process.

Several predisposing factors facilitate the stenosis process as follows: ${ }^{2}$

- prolonged intubation 
- repeated and trauma on intubation

- configuration and size of endotracheal tube

- material of the tube

- high tracheostomy

- bad humidification

- systemic disease

The types and classification of tracheal narrowing, stenosis can be classified in several ways:

Based on tissue forming types, stenosis can be classified as hard cicatrical and soft stenosis. ${ }^{7}$

The second classification of stenosis, is based on the shape of the stenosis: ${ }^{8}$

- annular stenosis

- tubular stenosis below the level of the Cricoid

- tubular stenosis stomal site

- lateral collaps of the tracheal lumen.

The third classification of the stenosis is based on the location of the lesion.

- above the stoma

- at the stoma site

- at the cuff site

- at the distal end of canule
Treatment attempted to overcome the stenosis are as follows:

- dilatation with or without injection of steroid

- dilatation and prolonged stenting

- luminal augmentation

- resection of the stenosis with primary reanstomosis.

\section{CASE REPORT}

A young man of 18 years of age had a traffic accident and suffered from cerebral contusion. Prolonged intubation has lead to the stenosis of the first and second ring of trachea. Figure 1 showed the stenotic part of the trachea, beneath the vocal cords, visualized endoscopically. A T-tube was inserted to overcome the stenosis, and 6 months later the tube was removed, but the stenosis re-occurred.

Resection of the stenotic area followed by end-to-end anastomosis was planned for permanent treatment. To prevent re-stenosis at the stitched area, A T-tube was inserted and act as a stent.

Figure 2 showed the horisontal incision line on skin of the neck. Horisontal incision will result in a cosmetically better wound healing.

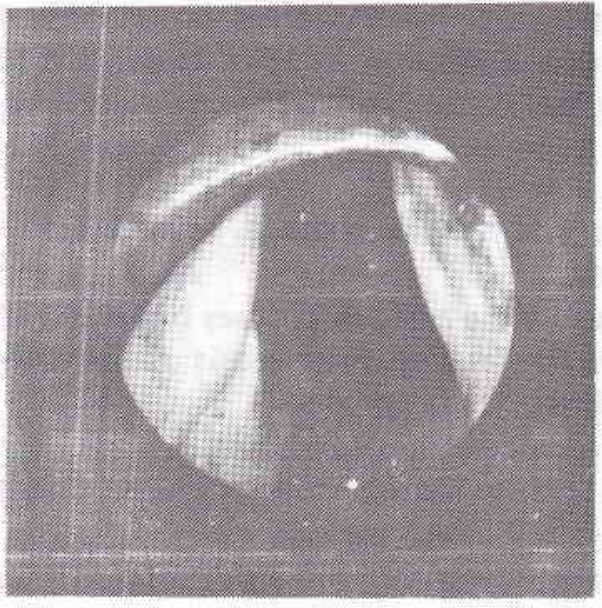

Figure 1. Endoscopic visualization of the stenotic part of the trachea under the vocal cords.

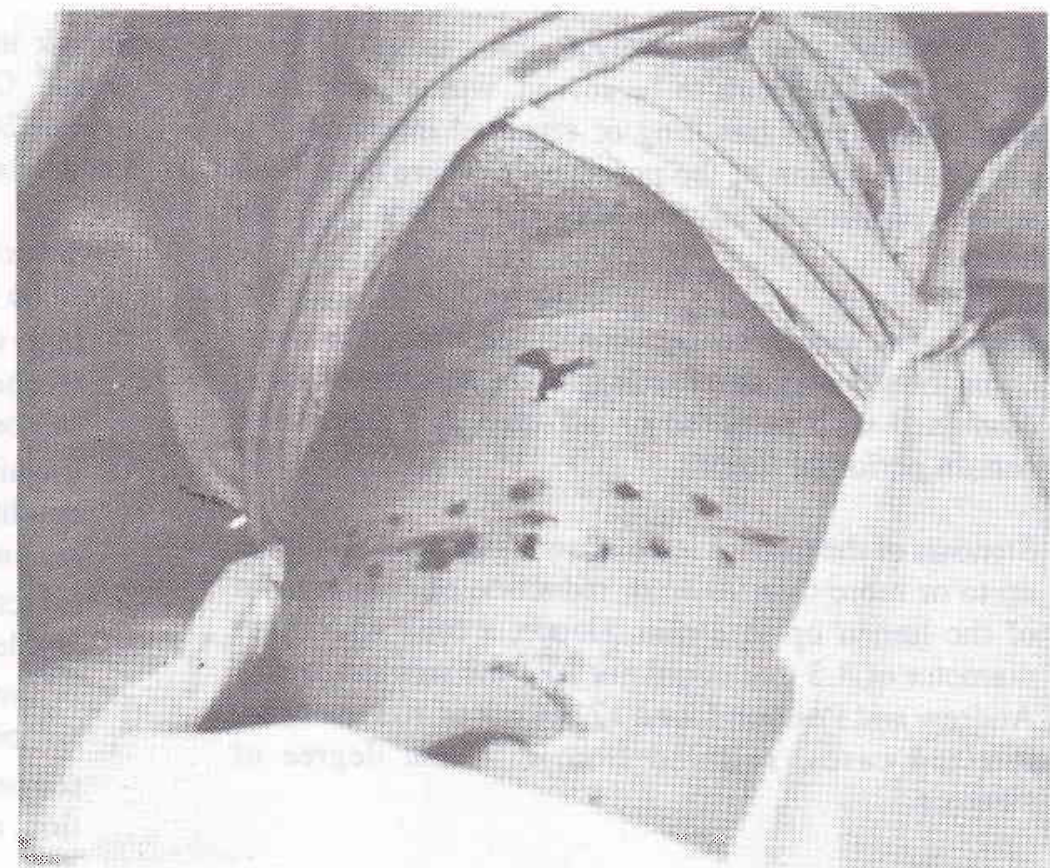

Figure 2. The sketch of horisontal incision line on skin of the neck. 
The hyoid bone was localized, as shown in figure 3 , to perform hyoid bone release, enabling longer approximation of the resected trachea.
The trachea was exposed, and incision was made on the upper and the lower part of stenotic area, as shown in figure 4.

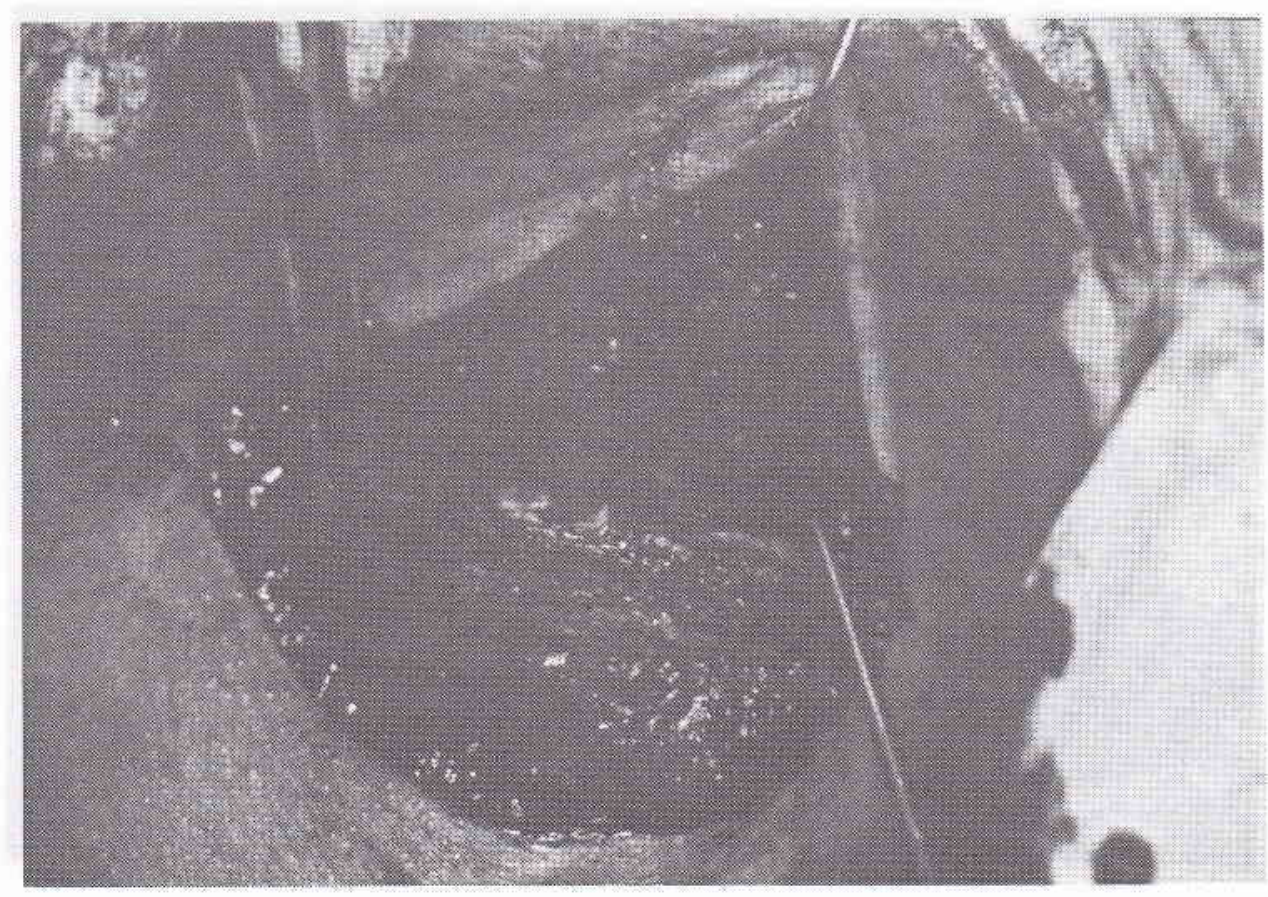

Figure 3. The hyoid bone localisation, to perform hyoid bone release

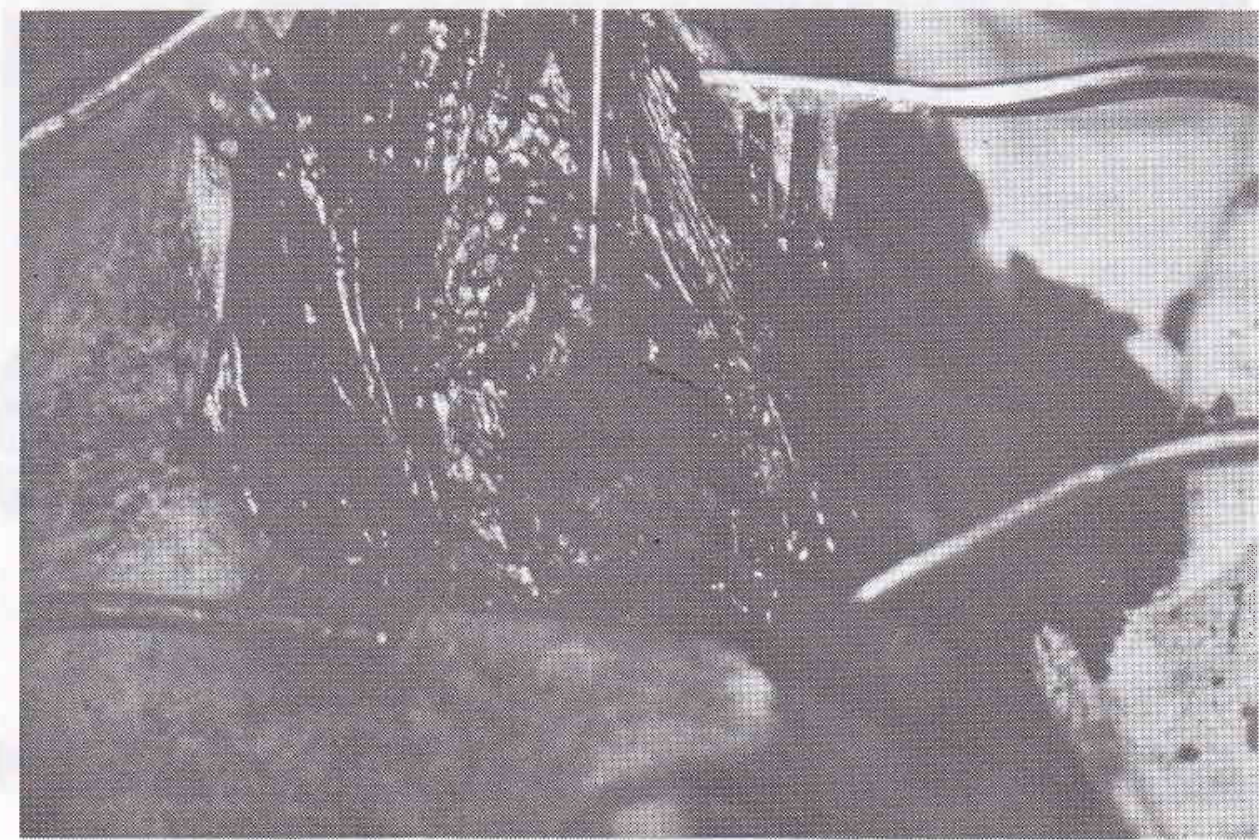

Figure 4. The trachea was exposed, and incision was made on the upper and the lower part of stenotic area. 
Figure 5 showed the T-tube to be inserted and act as tracheal stent to prevent restenosis on the stitched area.
Figure 6 showed the removed part of trachea, leaving the stenotic area uncovered.

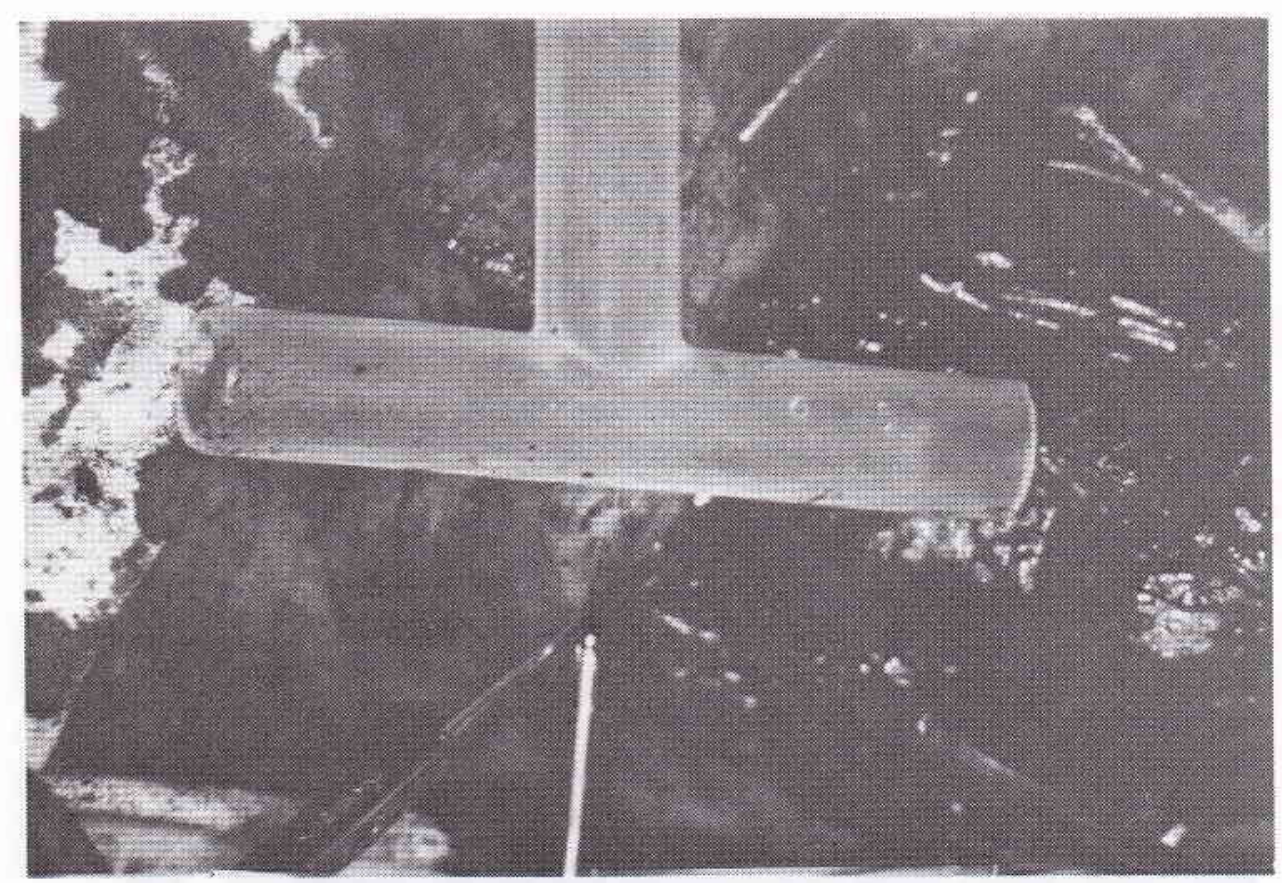

Figure 5. T-tube to be inserted and act as tracheal stent to prevent re-stenosis on the stitched area.

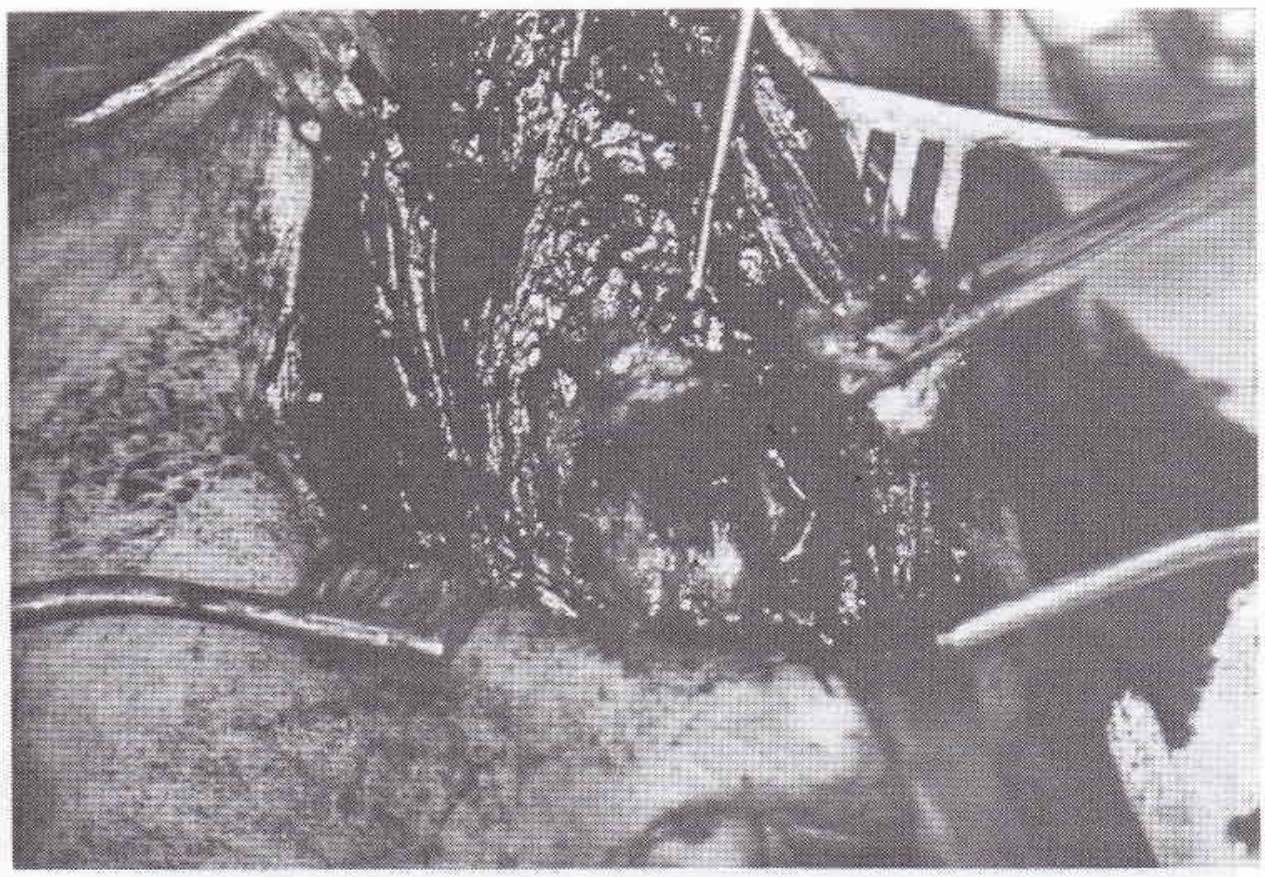

Figure 6. The removed part of trachea, leaving the stenotic area uncovered. 
Figure 7 showed the T-tube inserted through the resected part of the trachea, as tracheal stent preventing re-stenosis at the resected area.

The upper and lower part of resected area was then approximated and sutured, as shown in figure 8 .

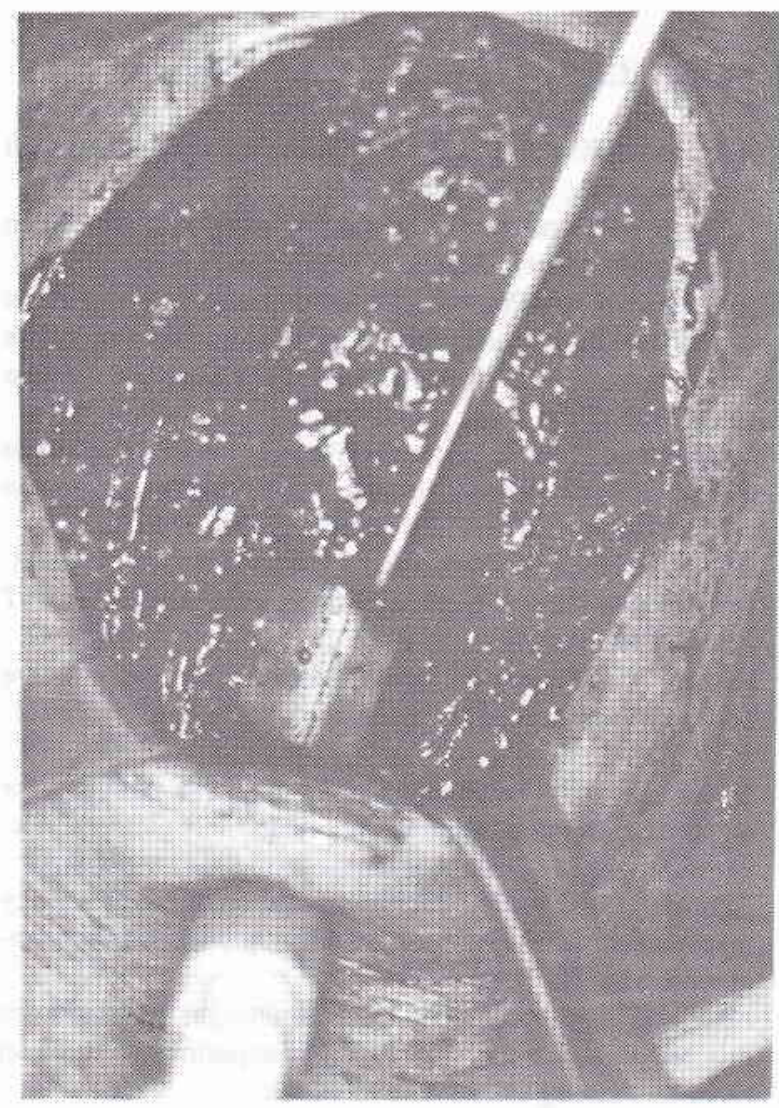

Figure 7. Insertion of T-tube through the resected part of the trachea.
Figure 9 showed the position of the upper end of T-tube within the trachea on post-operative endoscopic visualisation.

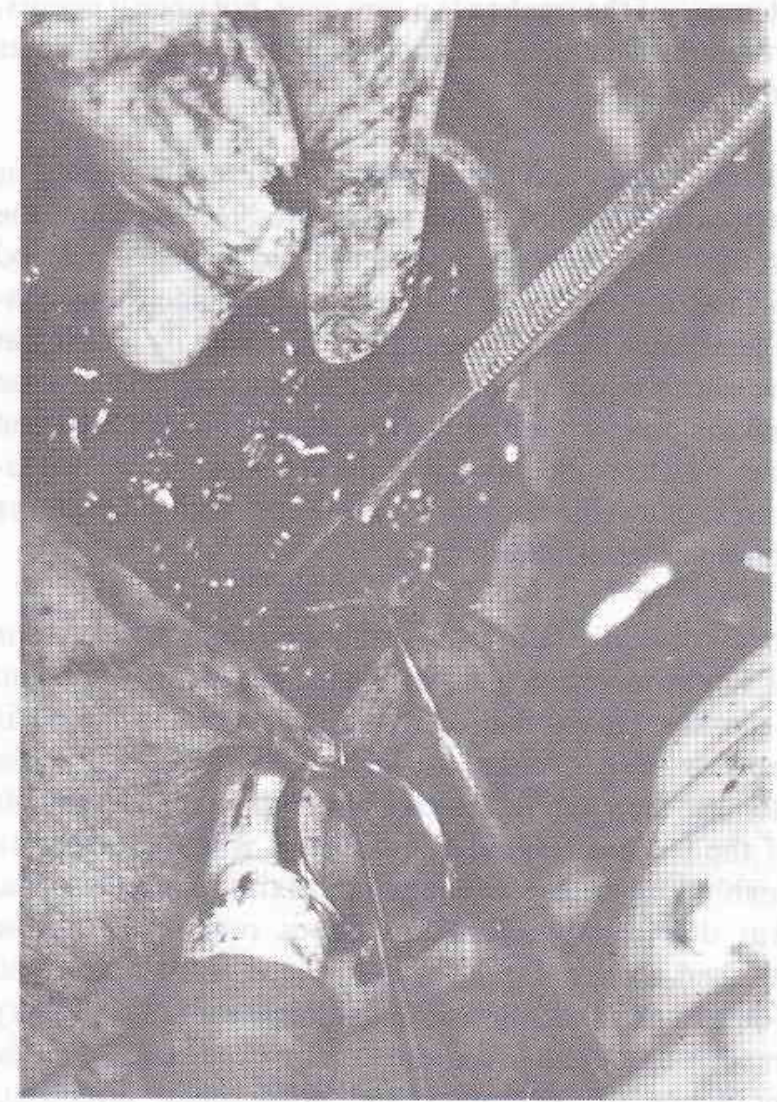

Figure 8. The upper and lower part of resected area was then approximated and sutured.

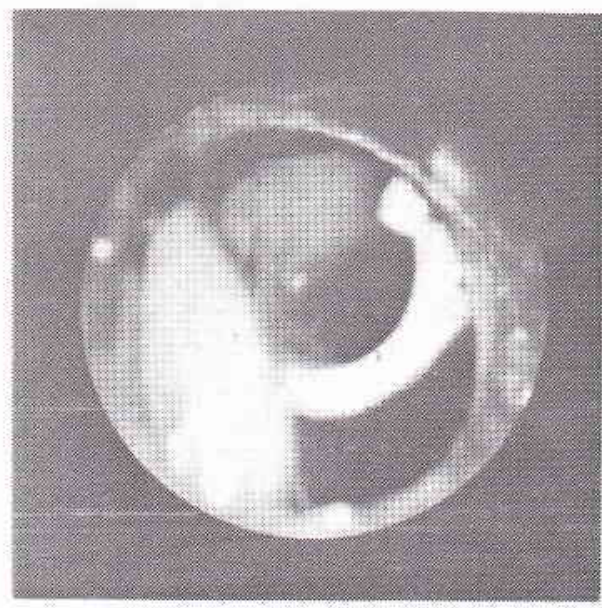

Figure 9. The position of the upper end of T-tube within the trachea on post-operative endoscopic visualisation. 
Six months later the T-tube was removed successfully, and the patient live uneventfully, without evidence of re-stenosis or respiratory distress.

\section{DISCUSSION}

Stenosis of the trachea is a rare case, but once it occurs, we might face problems to evercome, even sometimes unsolved.

Many experts had been employing and advocating or facilitating methods and procedures to overcome the problem but it seems that there is no standard method to treat this pathology. It should be judged and considered case by case, carefully calculated by looking at the entire situation and condition of both the disease and the patient. Sometime the problem needs repeated manipulation due to the stubborn lesion, and sometimes, a combination of methods and procedures should be considered.

In our case, dilatation and prolonged stenting by means of T-tube insertion was performed and lasting for about 6 months. On extubation it was shown that the stenosis reoccur. We decided to carry out resection of the stenotic area and followed by end-to- end anastomosis of the trachea. Hyoid bone release was performed to enable longer resection and approximation of trachea. But due to apprehension about restenosis of the stitched area, a T-tube was inserted and act as stent. Some experts mentioned that a stent was not necessary in such case. However, due to our experience that the incidence of secondary and nosocomial infections were high, besides giving high dose antibiotic, we put a stent on to prevent restenosis.

Six months later the T-tube was extubated successful$1 y$, and on the follow up no signs of restenosis or respiratory distress was noted.

\section{REFERENCES}

1. Hommerich $\mathrm{KW}$ and Fleming I. Classification of Laryngeal Stenosis. ORL, 1974; 36:100-6.

2. Holinger PH, Kutrick SL, Schild JA. Subglottic stenosis in infants and children. Ann. Otol. 1976; 85:591-9.

3. Andrews MJ and Pearson FG. Incidence and Pathogenesis of Tracheal injury following cuffed tube tracheostomy with assisted ventilation: Analysis of a Two Year Prospective study. Ann. Surg. 1971; 173:243-63.

4. Sardjono Soedjak S, Harmadji. Stenosis trakea. Dilebarkan dengan operasi trakeo-fisur dan kauter listrik. Kumpulan Naskah Konas PERHATI V Semarang, 1977; 401-5.

5. Abdoerrachman $\mathrm{H}$, Rusmaryono, Hermani B, and Munir M. Pemasangan Pipa - T Silikon pada penyempitan trakea. PIT I IKABI Jakarta, Nov. 17, 1982.

6. Rainer WG, Sauces M, and Lopez L. Tracheal stricture secondary to cuffed Tracheostomy tubes. Chest 1971; $59: 115-8$

7. Gates GA and Fernandez AT. Laryngotracheoplasty for acquired subglottic stenosis in infants and children. Experience with six cases. Laryngoscope 1978; 88:1468-76.

8. Eliacher I, Birkin JH, Simon K, Joachins HZ. Emergency management of tracheal stenosis. Retrograde tracheal bounginage. Ann. Otol. 1980; 89: 46-8.

9. Natvig K, and Olving JH. Tracheal changes in relation to different tracheostomy technique (An experimental study on rabbits). J Laring Otol 1981; 95:61-8. 